\title{
CUSTOMER SATISFACTION AND LOYALTY: A CASE STUDY FROM THE BANKING SECTOR
}

\author{
Rahman, $\mathbf{H}$.
}

Delivering superior service quality to customers in today's business environment is very crucial and important due the stiff competition in the local and international markets. The ability to provide high service quality will strengthen the image, enhance retention of customers, attracting new potential customers through customer satisfaction and loyalty. This study investigates the customer satisfaction and loyalty relationship in terms of basic service, advanced service employed by Jamuna Bank Limited and customer perceptions regarding cost and prestige of receiving banking service of the concerned bank. The study reveals that there is a significant relationship observed among advanced service, cost \& prestige and customer satisfaction. There is an insignificant relationship observed between basic service and customer satisfaction and finally a positive significant relationship observed between customer satisfaction and customer loyalty relationship.

JEL Classification: G21, M3

Keywords: Customer satisfaction; customer loyalty; basic service; advanced service

\section{Introduction}

The service sector has produced approximately two-thirds of worldwide GNP from twenty first century (Kara et al., 2005). Within the huge service sector, the banking sector is one of the most important entities; it has been growing relatively fast in the world. Commercial banks in Bangladesh are one of the key components of the economy of Bangladesh. Jamuna Bank Limited (JBL) is a Banking Company registered under the Companies Act, 1994. The bank started its operation as a private commercial bank in Bangladesh from $3^{\text {rd }}$ June 2001. Being a 3rd generation Bank of Bangladesh, it focuses on: remaining with time, managing change, developing human capital, and creating true customer value (JBL, 2013). With privatization, liberalization, deregulation and change in the technological environment, the banking industry has become more integrated especially private commercial banking in Bangladesh. This has created a highly competitive market environment in the banking industry. In today's business, a customer lost is a customer gained for a competitor. Due to stiffer market competition, commercial banks need more efforts to be done to retain their existing customers, i.e. as much as they do on acquiring them (R. Khouri, H. Boulos, 2013). The banking industry in Bangladesh today has become a very dynamic, competitive and complex environment where financial products and services offered by the commercial banks have only minor differences, where the industry situation is having a tremendous increase in customer demand and this require greater transformation with intense focus on customer satisfaction and loyalty.

This case study is an initiative to investigate the efforts of Jamuna Bank Limited to make customers satisfaction and loyalty a special focus of its basic banking service, advanced banking service and cost \& prestige issues of service received. However, basic banking, advanced banking and cost \& prestige factors have been considered to investigate satisfied and loyal customer of Jamuna bank limited. 


\section{Research Objectives}

A. To investigate respondents' demographics.

B. To investigate the relationship between basic service and customer satisfaction.

C. To investigate the relationship between advanced service and customer satisfaction.

D. To investigate the relationship between cost \& prestige and customer satisfaction.

E. To investigate the relationship between customer satisfaction and customer loyalty.

\section{Literature review}

Customer satisfaction and loyalty remain key issues of marketing scholars and marketers and will remain so in the future. There is considerable evidence that customer satisfaction and loyalty depend on service quality and lead to the higher profitability of the business. Quality in service can be determined by the extent to which customers' needs and expectations can be satisfied (Banerjee, 2012). Delivering superior service quality to customers in today's business environment is very crucial and important due the stiff competition in the market. The ability to provide high service quality will strengthen the image, enhance retention of customers, attracting new potential customers via positive word-ofmouth and eventually increase the profit of the business (Zeithaml, 1996). Service quality is one of the critical elements in determining the success and the competitiveness of a particular organization. Organizations such as banks can distance themselves from the competitors by performing high quality services for their customers. Service quality is one the favorite areas of researchers in their studies in retail banking industries (Johnston, 1997). Service quality has been considered as one of the most critical elements in the retail banking industry (Stanford, 1994). Zeithaml et al. (1990) found that in order for business organizations to be successful and survive in the competitive environment, the most critical strategy is to deliver superior service quality to their customers. Customer service quality is the driving force in both the traditional and virtual business worlds. In today's dynamic business environment, it is about building and sustaining a strong relationship with an organization's customers by understanding the ingredients of customer satisfaction (Banerjee, 2012).

Academic literature suggests that customer satisfaction is a function of the discrepancy between a customer's prior expectation and his or her perception regarding the purchase (Yi, 1990). Customer satisfaction can also be termed as the general attitude that customers have towards a product or service after they acquire and utilize it. In view of that, customer satisfaction is an evaluative judgment after the experience that consumer utilizes the product or service after a specific purchase selection (Oliver, 1992). Many studies have found that customer satisfaction plays a mediating role in the customer satisfaction and customer loyalty relationship. Akhbar and Parvez (2009), in their study on 302 telecommunication customers in Bangladesh telecommunication industry, have found customer satisfaction to be an important mediator between perceived service quality and customer loyalty. Kumar et al. (2010), in their study on 100 bank customers in India, have revealed that service quality fosters customers' attitudinal loyalty through latent customer satisfaction.

Enhancing customer loyalty has become a popular topic for managers, consultants, and academics. The arguments in support of loyalty are simple to understand. Loyal customers are reported to have higher customer retention rates, commit a higher share of their category spending to the firm, and are more likely to recommend others to become customers of the firm (Reichheld, Sasser, 1990). Loyalty is the commitment of a current customer in respect to a particular store, brand and service provider, when there are other alternatives that the current customer can choose instead (Shankar, Smith and Rangaswamy, 2003). It forms positive attitudes by producing repetitive purchasing behavior from time to time. There is a strong connection customer loyalty and firm's profit. Reicheld (2003) suggested that the most superior evidence of customer loyalty is the proportion amount in percentage of current customers who are having lots of enthusiasm to recommend a specific good or service to their friends. Whereas the attitudinal perspective, the current customers have a feeling of belonging to a specific product or service or commitment of the current customers towards a specific good or service. Pearson (1996) has defined customer loyalty as a mindset of the customers who hold favorable attitudes towards a company, commit to repurchase the company's product or service, and recommend the product or service to others.

\section{Research Methodology}

A scientific manner of planning, executing, and discussing important results is essential for doing any study, regardless of which fields are being investigated, such as managerial and social fields. Therefore, this chapter defines the research design, theoretical framework, hypothesis development, population samples, data collection procedures and the techniques of data analysis 
for examining the factors that affect customer satisfaction and loyalty with banking services in Jamuna Bank Limited, Bangladesh. The said factors are basic service, advanced service, cost and prestige, customer satisfaction and customer loyalty.

\subsection{Research Design}

This study is descriptive and hypothesis testing in natural. This study aimed to examine the factors that affect customer satisfaction and loyalty among the customers of banking services. This study involved hypothesis testing based on what has been developed in the framework. In the hypotheses testing, the relationship between the independent and dependent variables was explained. Finally, data was collected using a survey method where questionnaires were used to collect information.

\subsection{Research Framework}

\section{Figure 1 Theoretical Framework}

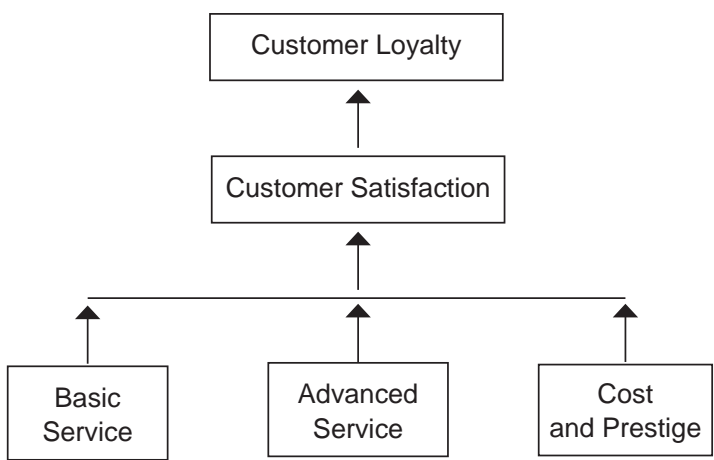

\subsection{Hypothesis Development}

In this study, the hypotheses have been selected based on the literature review mentioned above to describe the relationship among those variables that influence customer satisfaction and customer loyalty.

$\mathrm{H}_{1}$ : There is a positive/significant relationship between the basic service and customer satisfaction.

$\mathrm{H}_{2}$ : There is a positive/significant relationship between the advanced service and customer satisfaction

$\mathrm{H}_{3}$ : There is a positive/significant relationship between the cost \& prestige and customer satisfaction.

$\mathrm{H}_{4}$ : There is a positive/significant relationship between the customer satisfaction and customer loyalty.

\subsection{Population and Sample}

For the questionnaire survey, a convenient method of sampling was used. There is no available source for the addresses of customers of Jamuna Bank Limited. Therefore, friends, relatives, and other informal reference groups were used to locate the potential respondents in Bangladesh. Questionnaires were sent by email, postage mail and directly to 150 customers of Jamuna Bank Limited. The number of initial replies received was 90 . After screening the first round of replies, a second round of personal contacts was conducted by the researcher and finally 100 respondents were included in this study.

\subsection{Data Collection Technique}

This study is mainly based on primary data originating from a survey. For this purpose, a constructed questionnaire was developed. With the exception of the questions regarding demographic characteristics, issues relating to basic service, advanced service, cost \& prestige, customer satisfaction and loyalty were constructed, measured and investigated through a five point scale standardized by Brayfield-Rothe (1951). The scale consists of 25 statements; each statement has five options/ points such as strongly agree/ 5 , agree/ 4, undecided/3, disagree/ 2 , and strongly disagree/ 1 .

A pilot study on 10 respondents was conducted using the draft questionnaire. At the outcome of this phase, a few initially selected variables were dropped to avoid multicoliniarity problem. In addition, some rephrasing was done to arrive at a final version of the questionnaire for this study. The final questionnaire was put into operation by way of email, mail and personal survey.

\subsection{Data Analysis Technique}

The SPSS statistics software package was used for statistical analysis. Reliability of data was measured by using Chronbach's Alpha (Cornbach, 1951). The Chronbach Alpha was 0.906. An Alpha higher than that is suggested by Nunnally (1978) and therefore data collected can be considered reliable. Descriptive statistical techniques such as mean and standard deviation were used to measure the mean scores and their variability. Pearson Correlation was used to indicate correlations among the variables, Linear Regression analysis was used to test the hypothesis.

\section{Findings and Data Analysis}

\subsection{Respondent's Demographic}

The questionnaires were distributed to customers of Jamuna Bank Limited; among them were: $22 \%$ of Students, $49 \%$ of Service Holders, $28 \%$ of Businessmen 
and $1 \%$ of the respondents occupied the profession of Other. Thirty percent of the respondents' monthly gross income was below Tk 30,000, 33\% of the respondents' monthly gross income was within Tk 30,000-50,000, $17 \%$ of the respondents' monthly gross income was above Tk 50,000. Thirty-one percent of the respondents were under age 30 years, $46 \%$ were between $30-45$ years, $23 \%$ were above 45 years. Among them
$76 \%$ were married and $24 \%$ unmarried; $68 \%$ of the respondents were male and $32 \%$ female. Twenty-seven percent of the respondents connected with the bank below 5 years, 52\% connected within 5-10 years and $21 \%$ respondents connected above 10 years. Among the respondents education, one can see: $7 \%$ SSC, $15 \%$ HSC, 32\% Bachelor, 45\% Master, and 1\% have a $\mathrm{PhD}$ degree.

Table 1 Survey, 2013

\begin{tabular}{|c|c|c|c|c|}
\hline \multicolumn{2}{|c|}{ Respondent's Demographic } & Frequency & Percent & Cumulative Percent \\
\hline \multirow{5}{*}{ Profession } & Student & 22 & 22.0 & 22.0 \\
\hline & Service Holder & 49 & 49.0 & 71.0 \\
\hline & Business man & 28 & 28.0 & 99.0 \\
\hline & Others & 1 & 1.0 & 100.0 \\
\hline & Total & 100 & 100.0 & \\
\hline \multirow{4}{*}{ Gross Income } & bellow 30000 & 30 & 30.0 & 30.0 \\
\hline & $30000-50000$ & 53 & 53.0 & 83.0 \\
\hline & above 50000 & 17 & 17.0 & 100.0 \\
\hline & Total & 100 & 100.0 & \\
\hline \multirow{4}{*}{ Age } & below 30 & 31 & 31.0 & 31.0 \\
\hline & $30-45$ & 46 & 46.0 & 77.0 \\
\hline & above 45 & 23 & 23.0 & 100.0 \\
\hline & Total & 100 & 100.0 & \\
\hline \multirow{3}{*}{ Marital Status } & Yes & 76 & 76.0 & 76.0 \\
\hline & No & 24 & 24.0 & 100.0 \\
\hline & Total & 100 & 100.0 & \\
\hline \multirow{3}{*}{ Sex } & Male & 68 & 68.0 & 68.0 \\
\hline & Female & 32 & 32.0 & 100.0 \\
\hline & Total & 100 & 100.0 & \\
\hline \multirow{4}{*}{$\begin{array}{l}\text { Year of } \\
\text { Connection }\end{array}$} & Below 5 & 27 & 27.0 & 27.0 \\
\hline & $5-10$ & 52 & 52.0 & 79.0 \\
\hline & above 10 & 21 & 21.0 & 100.0 \\
\hline & Total & 100 & 100.0 & \\
\hline \multirow{6}{*}{ Education } & SSC & 7 & 7.0 & 7.0 \\
\hline & HSC & 15 & 15.0 & 22.0 \\
\hline & Bachelor & 32 & 32.0 & 54.0 \\
\hline & Master & 45 & 45.0 & 99.0 \\
\hline & PhD & 1 & 1.0 & 100.0 \\
\hline & Total & 100 & 100.0 & \\
\hline
\end{tabular}

\subsection{Descriptive Statistics}

Descriptive statistics such as mean and percentage were used to measure the percentage of variables and also used to describe the mean of dependent and independent variables. Table 2 shows the mean value of basic service was 4.22 and standard deviation (.63469). The mean value of advanced service was 3.9780 and standard deviation (.65003). The mean value of cost and prestige was 3.9820 and standard deviation (.66551). The mean value of customer satisfaction was 4.0540and standard deviation (.60024). The mean value of customer loyalty was 4.2060 and standard deviation (.49682) with minimum value was 1.00 , and the maximum value was 5.00 and therefore variability of each factor is measured in terms of standard deviation. 
Table 2 Descriptive Statistics (Survey, 2013)

\begin{tabular}{|c|c|c|c|c|c|c|}
\hline Factors & Statements & $\mathbf{N}$ & $\bar{X}$ & $\sigma$ & Average $\bar{X}$ & Average $\sigma$ \\
\hline \multirow{5}{*}{ Basic Service } & Help in Opening Account & 100 & 4.1900 & .84918 & \multirow{5}{*}{4.2200} & \multirow{5}{*}{63469} \\
\hline & Advice on deposit & 100 & 4.1400 & .91032 & & \\
\hline & Deposit is Secure & 100 & 4.4800 & .59425 & & \\
\hline & Credit Facilities & 100 & 4.0700 & 1.03724 & & \\
\hline & Security in Bank Premises & 100 & 4.2200 & .75985 & & \\
\hline \multirow{2}{*}{$\begin{array}{l}\text { Advanced } \\
\text { Service }\end{array}$} & New Facilities for customer & 100 & 3.9000 & .92660 & \multirow{5}{*}{3.9780} & \multirow{5}{*}{.65003} \\
\hline & Overtime Banking Facilities & 100 & 3.7000 & 1.03962 & & \\
\hline \multirow{3}{*}{$\begin{array}{l}\text { (Independent } \\
\text { variable) }\end{array}$} & Good Internal Physical Environment & 100 & 4.1600 & .82536 & & \\
\hline & Confidentiality on Deposit & 100 & 4.1800 & .77041 & & \\
\hline & Available Service Provider & 100 & 3.9700 & 1.00960 & & \\
\hline \multirow{5}{*}{$\begin{array}{l}\text { Cost and } \\
\text { Prestige } \\
\text { (Independent } \\
\text { variable) }\end{array}$} & Responsive to Customer Complain & 100 & 3.9400 & .89691 & \multirow{5}{*}{3.9820} & \multirow{5}{*}{.66551} \\
\hline & Convenient Service Charges & 100 & 3.9500 & .88048 & & \\
\hline & Friendly Attitude & 100 & 3.9600 & .90921 & & \\
\hline & Positive Mentality & 100 & 4.0700 & 1.01757 & & \\
\hline & Contribution for Society & 100 & 3.9900 & .94810 & & \\
\hline \multirow{5}{*}{$\begin{array}{l}\text { Customer } \\
\text { Satisfaction } \\
\text { (Intervening } \\
\text { variable) }\end{array}$} & Ease of Transaction & 100 & 3.9700 & .91514 & \multirow{5}{*}{4.0540} & \multirow{5}{*}{.60024} \\
\hline & Prompt Service & 100 & 4.0400 & .85185 & & \\
\hline & Getting Advice & 100 & 4.0100 & .92654 & & \\
\hline & Arrangement for Customer & 100 & 4.1100 & .88643 & & \\
\hline & Attractive Interest Rate & 100 & 4.1400 & .75237 & & \\
\hline \multirow{5}{*}{$\begin{array}{l}\text { Customer } \\
\text { Loyalty }\end{array}$} & Value Added Service & 100 & 4.1300 & .69129 & \multirow{5}{*}{4.2060} & \multirow{5}{*}{.49682} \\
\hline & Interested to Deposit & 100 & 4.2900 & .59110 & & \\
\hline & Take Credit Facility & 100 & 4.2100 & .79512 & & \\
\hline & Inform New Banking Service & 100 & 4.1100 & .77714 & & \\
\hline & Strong Relationship with bank & 100 & 4.2900 & .70058 & & \\
\hline
\end{tabular}

\subsection{Correlations among Variables}

Table 3 Correlations

\begin{tabular}{|c|c|c|c|c|c|c|}
\hline & & $\begin{array}{l}\text { Basic } \\
\text { Service }\end{array}$ & $\begin{array}{l}\text { Advanced } \\
\text { Service }\end{array}$ & $\begin{array}{l}\text { Cost and } \\
\text { Prestige }\end{array}$ & $\begin{array}{l}\text { Customer } \\
\text { Satisfaction }\end{array}$ & $\begin{array}{c}\text { Customer } \\
\text { Loyalty }\end{array}$ \\
\hline \multirow{3}{*}{$\begin{array}{l}\text { Basic } \\
\text { Service }\end{array}$} & Pearson Correlation & 1 & & & & \\
\hline & Sig. (2-tailed) & & & & & \\
\hline & $\mathbf{N}$ & 100 & & & & \\
\hline \multirow{3}{*}{$\begin{array}{l}\text { Advanced } \\
\text { Service }\end{array}$} & Pearson Correlation & $.590^{\star *}$ & 1 & & & \\
\hline & Sig. (2-tailed) & .000 & & & & \\
\hline & $\mathbf{N}$ & 100 & 100 & & & \\
\hline \multirow{3}{*}{$\begin{array}{l}\text { Cost and } \\
\text { Prestige }\end{array}$} & Pearson Correlation & $.445^{\star \star}$ & $.607^{\star *}$ & 1 & & \\
\hline & Sig. (2-tailed) & .000 & .000 & & & \\
\hline & $\mathrm{N}$ & 100 & 100 & 100 & & \\
\hline \multirow{3}{*}{$\begin{array}{l}\text { Customer } \\
\text { Satisfaction }\end{array}$} & Pearson Correlation & $.376^{\star *}$ & $.586^{\star *}$ & $.700^{\star *}$ & 1 & \\
\hline & Sig. (2-tailed) & .000 & .000 & .000 & & \\
\hline & $\mathbf{N}$ & 100 & 100 & 100 & 100 & \\
\hline \multirow{3}{*}{$\begin{array}{l}\text { Customer } \\
\text { Loyalty }\end{array}$} & Pearson Correlation & $.297^{\star *}$ & $.482^{* *}$ & $.441^{* *}$ & $.573^{\star *}$ & 1 \\
\hline & Sig. (2-tailed) & .003 & .000 & .000 & .000 & \\
\hline & $\mathbf{N}$ & 100 & 100 & 100 & 100 & 100 \\
\hline
\end{tabular}

Note: ${ }^{* *}$. Correlation is significant at the 0.01 level (2-tailed). 
Table 4 Model Summary

\begin{tabular}{|l|c|c|c|c|}
\hline Model & R & R Square & Adjusted R Square & Std. Error of the Estimate \\
\hline 1 & $.729^{\mathrm{a}}$ & .532 & .517 & .41701 \\
\hline
\end{tabular}

a. Predictors: (Constant), Cost and Prestige, Basic Service, Advanced Service

Table 5 ANOVA ${ }^{\mathrm{b}}$

\begin{tabular}{|l|l|c|c|c|c|c|}
\hline \multicolumn{2}{|l|}{ Model } & Sum of Squares & df & Mean Square & F & Sig. \\
\hline \multirow{2}{*}{1} & Regression & 18.974 & 3 & 6.325 & 36.371 & $.000^{\mathrm{a}}$ \\
\cline { 2 - 7 } & Residual & 16.694 & 96 & .174 & & \\
\cline { 2 - 7 } & Total & 35.668 & 99 & & & \\
\hline
\end{tabular}

a. Predictors: (Constant), Cost and Prestige, Basic Service, Advanced Service

b. Dependent Variable: Customer Satisfaction

Bivariate Correlations is used to know the nature, direction and significance of the bivariate relationship of the variables of this study. Therefore, the researcher used the Bivariate Correlations procedure to compute Pearson's correlation coefficient. Table 3 shows the Pearson's correlation coefficient of the variables of the study. A rule of thumb is that multicollinearity may be a problem if a correlation is $>.90$, in the correlation matrix formed by all the independent variables (Coakes, S. J. and L. G. Steed, 2000). Based on the analysis presented in Table 3, the results show that there is a positive correlation between the variables, the correlation between basic service and advanced service, indicates that there was a significant correlation between two variables with coefficient correlation $\mathrm{r}=.590$ at $p<0.00$ level. The correlation between basic service and Cost and Prestige, indicates that there was a significant correlation between two variables with coefficient correlation $r=.445$ at $p<0.00$ level. The correlation between basic service and Customer Satisfaction, indicates that there was a significant correlation between two variables with coefficient correlation $r=.376$ at $p<0.00$ level. The correlation between basic service and Customer Loyalty, indicates that there was a significant correlation between two variables with coefficient correlation $r=.297$ at $\mathrm{p}<0.03$ level. The correlation between Advanced Service and Cost and Prestige, indicates that there was a significant correlation between two variables with coefficient correlation $r=.607$ at $p<0.00$ level. The correlation between Advanced Service and Customer Satisfaction, indicates that there was a significant correlation between two variables with coefficient correlation $r=.586$ at $p<0.00$ level. The correlation between Advanced Service and Customer Loyalty, indicates that there was a significant corre- lation between two variables with coefficient correlation $r=.482$ at $p<0.00$ level. The correlation between Cost and Prestige and Customer Satisfaction, indicates that there was a significant correlation between two variables with coefficient correlation $r=.700$ at $p<0.00$ level. The correlation between Cost and Prestige and Customer Loyalty, indicates that there was a significant correlation between two variables with coefficient correlation $r=.441$ at $p<0.00$ level. The correlation between Customer Satisfaction and Customer Loyalty, indicates that there was a significant correlation between two variables with coefficient correlation $r=.573$ at $p<0.00$ level.

\subsection{Regression Analysis}

Multiple regressions were used to study the effect of the independent variables $(\mathrm{X} 1=$ Basic service, $\mathrm{X} 2=$ Advanced service, $\mathrm{X} 3=$ Cost and prestige) to dependent variable ( $\mathrm{Y}=$ customer satisfaction). Significance level for, Basic service, Advanced service, and Cost and prestige are accepted on Alpha $(\alpha)=1 \%$, significance level $=99 \%$ significant at $1 \%(*)$. Table 4 shows the analysis of multiple regressions. The value of $R$ was (.729), the value of $R$ square was (.529) and the standard error of the estimate was (.41701). The model summary and the data are shown in Table 4.

The results from Table 4 show that the regression equation explains more than $53.2 \%$ of the variability in customer satisfaction. This is an acceptable level for R2 in explaining variability of customer satisfaction. The results of the multiple regression models indicate that customer expectation, perceived quality, perceived value and corporate image explain the variance in customer satisfaction. The value of the R2 ( $\mathrm{R}$ Square) is an acceptable value for explaining variability of customer satisfaction. Analysis 
Table 6 Coefficients ${ }^{a}$

\begin{tabular}{|c|c|c|c|c|c|c|c|c|}
\hline \multirow{2}{*}{\multicolumn{2}{|c|}{ Model }} & \multicolumn{2}{|c|}{$\begin{array}{l}\text { Unstandardized } \\
\text { Coefficients }\end{array}$} & \multirow{3}{*}{$\begin{array}{c}\begin{array}{c}\text { Standardized } \\
\text { Coefficients }\end{array} \\
\text { Beta }\end{array}$} & \multirow[t]{2}{*}{$\mathbf{t}$} & \multirow[t]{2}{*}{ Sig. } & \multicolumn{2}{|c|}{ Collinearity Statistics } \\
\hline & & B & Std. Error & & & & Tolerance & VIF \\
\hline \multirow{4}{*}{1} & (Constant) & 1.202 & .320 & & 3.759 & .000 & & \\
\hline & Basic Service & -.025 & .083 & -.027 & -.307 & .760 & 640 & 1.562 \\
\hline & Advanced Service & .248 & .091 & .268 & 2.729 & .008 & .504 & 1.984 \\
\hline & Cost and Prestige & .495 & .080 & .549 & 6.194 & .000 & .620 & 1.613 \\
\hline
\end{tabular}

a. Dependent Variable: Customer Satisfaction

Table 7 Model Summary

\begin{tabular}{|l|c|c|c|c|}
\hline Model & $\mathbf{R}$ & $\mathbf{R}$ Square & Adjusted R Square & Std. Error of the Estimate \\
\hline $\mathbf{1}$ & $.573 a$ & .329 & .322 & .40912 \\
\hline
\end{tabular}

a. Predictors: (Constant), Customer Satisfaction

of variance test statistics (ANOVA) indicates that the model is significant at $\alpha=0.000$. Table 7 provides the information on the significance of the model indicating a significant $\mathrm{p}$-value of 0.000 . The AVOVA findings are shown in Table 5 below.

Table 5 shows the ANOVA findings that the independent variables as a whole have significant relationships with customer satisfaction $(F=36.371)$ ( $\operatorname{Sig} 0.000)$. Furthermore, this result is supported by the significant correlation among the variables. The findings show that the multiple regression coefficients for all independent variables with customer satisfaction is $R(.729)$ and $R$ square (.532). The number of independent variables relative to the sample size influences $R$ square. The adjusted $R$ square becomes smaller as fewer observations per independent variable are made. It reflects the decreasing ratio of estimated coefficients to the sample size and compensates for (Over fitting) of the data as $\mathrm{R}$ square increases (Hair, et. al., 2006). As shown in Table 8 the Collinearity Statistics VIF result for basic service $=1.562$, advanced service $=1.984$, cost $\&$ prestige $=1.613$. These results are significant and acceptable complying with standard requirement value for Collinearity Statistics VIP of less than 10, standard requirement VIF $<10$ (Coake and Steed, 2007).

Table 6 shows that all the values of the T-statistic are significant for advanced service and cost \& prestige and insignificant for basic service. Thus, all the independent variables can be retained in the model. In other word, these variables can explain the change in customer satisfaction. Table 6 shows that two independent variables were found to be very significant and supportive of the hypotheses regression analysis except basic service; value was not statistically significant and it does not supported the hypothesis.

Multiple regression analysis in Table 6 was employed to determine whether basic service has an effect on customer satisfaction; the result of regression analysis revealed that there was no significant relationship between basic service and customer satisfaction (.760); $B=-.025$. Because the significant value can't be met, the requirement which is the value of significant should be less than 0.05 . Therefore, this hypothesis is rejected. In contrast, the multiple regression analysis as in Table 6 was employed to determine whether the advanced service has an effect on customer satisfaction; the result of regression analysis revealed that there was a positive relationship between these two variables at the significance level (.008) with $B=.248$. Therefore, this hypothesis is supported and met the requirement. The multiple regression analysis in Table 6 was employed to determine whether the Cost and Prestige has an effect on customer satisfaction; the result of regression analysis revealed that there was a positive relationship between these two variables at the significance level (.000); $B=.495$. The hypothesis is accepted because the result of significance is less than 0.05 (Significance requirement standard <0.05).

Table 07 shows the analysis of multiple regressions. The value of $R$ was (.573), the value of $R$ square was (.329) and the standard error of the estimate was (.40912). The model summary and the data are shown in Table 07.The 
Table 8 ANOVA ${ }^{b}$

\begin{tabular}{|c|l|c|r|r|r|r|}
\hline \multicolumn{2}{|l|}{ Model } & Sum of Squares & df & Mean Square & F & Sig. \\
\hline \multirow{4}{*}{1} & Regression & 8.034 & 1 & 8.034 & 47.997 & $.000 a$ \\
\cline { 2 - 6 } & Residual & 16.403 & 98 & .167 & \\
\cline { 2 - 6 } & Total & 24.436 & 99 & & \\
\hline
\end{tabular}

a. Predictors: (Constant), Customer Satisfaction

b. Dependent Variable: Customer Loyalty

Table 9 Coefficients ${ }^{a}$

\begin{tabular}{|c|c|c|c|c|c|c|c|c|}
\hline \multirow{2}{*}{\multicolumn{2}{|c|}{ Model }} & \multicolumn{2}{|c|}{$\begin{array}{l}\text { Unstandardized } \\
\text { Coefficients }\end{array}$} & \multirow{3}{*}{$\begin{array}{c}\text { Standardized } \\
\text { Coefficients } \\
\text { Beta } \\
\end{array}$} & \multirow{3}{*}{$\begin{array}{c}\mathbf{t} \\
8.130 \\
\end{array}$} & \multirow{3}{*}{$\begin{array}{l}\text { Sig. } \\
.000\end{array}$} & \multicolumn{2}{|c|}{ Collinearity Statistics } \\
\hline & & B & Std. Error & & & & Tolerance & VIF \\
\hline \multirow[b]{2}{*}{1} & (Constant) & 2.282 & .281 & & & & & \\
\hline & $\begin{array}{l}\text { Customer } \\
\text { Satisfaction }\end{array}$ & .475 & .069 & .573 & 6.928 & .000 & 1.000 & 1.000 \\
\hline
\end{tabular}

a. Dependent Variable: Customer Loyalty

Table 10 The Summary of Hypotheses Results

\begin{tabular}{|l|l|}
\hline Hypotheses & Results \\
\hline $\mathrm{H}_{1}:$ There is a positive/significant relationship between the basic service and customer satisfaction & Rejected \\
\hline $\mathrm{H}_{2:}$ There is a positive/significant relationship between the advanced service and customer satisfaction. & Accepted \\
\hline $\mathrm{H}_{3:}$ There is a positive/significant relationship between the cost \& prestige and customer satisfaction. & Accepted \\
\hline $\mathrm{H}_{4}:$ There is a positive/significant relationship between the customer satisfaction and customer loyalty & Accepted \\
\hline
\end{tabular}

results from Table 07 show that the regression equation explains more than $32.9 \%$ of the variability in loyalty. Collinearity Statistics VIF result for customer satisfaction $=1.000$. Collinearity Statistics VIP of less than 10, meet the standard requirement.

These multiple regressions were used to study the effect of the independent variables (X1 = Customer Satisfaction) to dependent variable ( $\mathrm{Y}=$ Customer Loyalty). Finally, the multiple regression analysis in Table 08 was employed to determine whether the Customer Satisfaction has an effect on customer loyalty; the result of regression analysis revealed that there was a positive relationship between these two variables at the significance level (.000); $B=.475$. The hypothesis is accepted because the result of significance is less than 0.05 (Significance requirement standard <0.05).

\section{Managerial Implications}

Measuring customer satisfaction and loyalty relationship in terms of basic service, advanced service, cost $\&$ prestige investigated therefore positive significant relationship observed among advanced service, cost \& prestige and customer satisfaction and loyalty relationship and insignificant for basic service employed by Jamuna Bank Limited. The customer becomes very much dynamic and the customer satisfaction relationship may fluctuate suddenly; therefore, special concentration of Jamuna Bank Limited on basic service should be employed for maximizing customer value and preferences for making them satisfied and loyal. Employees should be well trained to understand the needs and preferences of customers and provide services accordingly that the organization is supposed to provide for its customers. Customer satisfaction and loyalty relationship in terms of service quality dimensions is complex and dynamic. Therefore special attention from service providers on customer value maximization and expectation fulfillment should be employed in order to make them satisfied and loyal.

With the growing up of the world economy, a dramatic change has been observed in the banking sector. This has brought higher employment opportunities, increases 
in income level, and changes in consumption patterns and consequently there emerges a competitive environment. Specifically, the expansion of banking business, along with customized services, has created an implied competition in this sector. This competition has created a service gap for their internal and external customers. The scenario has created an urge for the bank policy makers to identify the underlying reasons and brought them into consideration of the customer satisfaction and loyalty issues. In such a situation, customer satisfaction and loyalty of bank customer become important issues that have to be taken care of in order to achieve ultimate goals of the banking sector. Since one of the key factors of an organization is its customer and the success/failure of the organization largely depends on their satisfaction/ dissatisfaction.

\section{References}

Akbar, M. M., Parvez, N. (2009). Impact of Service Quality, Trust and Customer Satisfaction on Customer Loyalty. ABAC Journal, 29 (1): 24-38.

Arun Kumar, S., Tamil Mani, B. Mahalingam, S., Vanjikovan, M. (2010). Influence of Service Quality on Attitudinal Loyalty in Private Retail Banking: An Empirical Study. Journal of Marketing, 65 (6): 36-47.

Banerjee, N. (2012). A Comparative Study of Customers' Perceptions of Service Quality Dimensions between Public and Private Banks in India. International Journal of Business Administration. 3 (5): 34.

Brayfield, A. H., Rothe, H. F. (1951). An Index of Job Satisfaction. Journal of Applied Psychology, 35 (5): 307-311. http://dx.doi.org/10.1037/h0055617

Coakes, S. J., Steed, L. G. (2007). SPSS: Analysis without anguish: Version 14.0 for Windows. Milton, Qld: John Wiley \& Sons.

Cronbach L. J. (1951). Coefficient Alpha and Internal Structure of Test. Psychometrika. 16: 297-334.

Hair, J.F., Black, W.C., Babin, A.L., Tatham, R.L. (2006) Multivariate Data Analysis. 6Th Edition. Upper Saddle River, NJ: Pearson Prentice Hall.

Johnston, R.. (1997). Identifying the critical determinants of service quality in retail banking: importance and effects. The International Journal of Bank Marketing. 15 (4): 111-119.
Kara, A., Lonial, S., Tarım, M., Zaim, S. (2005). A paradox of service quality in turkey the seemingly contradictory relative importance of tangible and intangible determinants of service quality. European Business Review, 17 (1): 5-20. http://dx.doi. org/10.1108/09555340510576230

Khouri, R., Boulos, H. (2013). Conceptual Framework Development for Customer Loyalty in Malaysian Commercial Banking Industry. European Journal of Innovation and Business, 11.

Nunnally, J. L. (1978). Psychometric Theory. New York.: McGraw Hill Company.

Oliver, R. L. (1992). An investigation of the attribute basis of emotion and related affects in consumption: suggestions for a stage-specific satisfaction framework. Advance in Consumer Research, 19: 237-244.

Pearson, N. (1996). Building brands directly: creating business value from customer Relationships. Macmillionlan Business, 20 (6): 68-82.

Reichheld, F.F., Sasser Jr., W. E (1990). Zero defections: quality comes to services. Harvard Business Review, 68 (5): 105-111.

Shankar, V., Smith, A. K., Rangaswamy, A. (2003). Customer satisfaction and loyalty in online and offline encounters. International Journal of Research in Marketing, 20(2): 153-175.

Stafford, M., (1994). How customers perceive SQ. Journal of Retail Banking, 17 (2): 29- 38.

Reichheld, F. F. (2003). The One Number You Need to Grow. Harvard Business Review, 81 (12): 485-491.

Yi, Y. (1990). A Critical Review of Consumer Satisfaction. Review of Marketing. 4: 68-123

Zeithaml, V. A., Parasuraman, A., Berry, L. L. (1990). Delivering Quality Service: Balancing Customer Perceptions and Expectations. New York, NY: The Free Press.

Zeithaml, V. A., Berry, L. L., Parasuraman, A. (1996). The Behavioral Consequences of Service Quality. Journal of Marketing, 60: 31-46.

Author

Md. Hasebur Rahman Assistant Professor

Department of Business Administration Pabna University of Science and Technology

Pabna-6600, Bangladesh hasebur7208@yahoo.com 